International Journal of Public Finance
E-ISSN: $2548-0499 \quad$ DOI: $10.30927 /$ ijpf.319885
Vol./Cilt: 1 | Issue/Sayı: 2 | (2016), pp. $146-167$
journal homepage: http://dergipark.gov.tr/ijpf

\title{
Vergi Hukuku ve Ceza Hukuku Normları Açısından Pişmanlık: Sorunlar-Yaklaşımlar-Çözüm Önerileri*
}

\author{
Penitence in Terms of Tax Law and Criminal Law Norms: \\ Problems-Approaches-Solution Proposal
}

\author{
Burçin BOZDOĞANOĞLU ${ }^{1}$
}

\begin{abstract}
ARTICLE INFO
Received: 26.01.2016

Received in revised form: 05.04.2016

Accepted: 11.04.2016

Available online:

26.12.2016

JEL classification:

K34, H26, K14

\section{Keywords:}

Penitence, Tax Loss,

Tax Evasion

A B S T R A C T

In our country, despite basis of statement is accepted, determination of reported basis of assessment could be done by tax audition. Located in Tax Law Article 371 penitence and rectification provides the ability to resolve disputes to taxpayer at the administrative stage providing certain conditions, on taxes based on declaration.

According to Article 359 of Tax Law, based on the conditions mentioned in Article 371 of the law states with penitence about the status of the penitence to the relevant authorities it is started whether the application of criminal smuggling. So, "payment" condition in Article 371 which is currently taken a place among the conditions to benefit from located penitence institution and tax loss that prevents withdrawal penalty, the issue is not the punishment of trafficking in terms of the current is still in the case of a subject that cannot be agreed upon. However the fate of specified period of time for penitence institute existence of force majeure is controversial issue.

In this context; the processing of tax evasion rather than tax loss without penitence institution evaluation of the implementation of equality in taxation. Results can occur within the framework of the provisions on the grounds penitence tax declarations which are not accepted for the reason of given without tax loss rather than a move to focus on the value of properties.

In our study, these issues are evaluated, based on tax law and criminal law norms and offers opinions and suggestions for issues raised.
\end{abstract}

15-19 Mayıs 2016 tarihleri arasında düzenlenen 31. Türkiye Maliye Sempozyumu'nda sunulan metnin gözden geçirilmiş ve düzeltilmiş hâlidir.

1 Doç. Dr., Siirt Üniversitesi İktisadi İdari Bilimler Fakültesi Maliye Bölümü, burcindogan@gmail.com 
MAKALE BígGisi

Alındı: 26.01.2016

Gözden geçirilmiş alındı: 05.04.2016

Kabul: 11.04.2016

Yayın: 26.12.2016

\section{JEL Kodu:}

$\mathrm{K} 34, \mathrm{H} 26, \mathrm{~K} 14$

Anahtar Kelimeler: Pişmanlık, Vergi Ziyaı, Vergi Kaçakçılığı

\section{ÖZET}

Ülkemizde beyan esasına dayalı bir vergileme sistemi benimsenmiş olmakla birlikte, bildirilen matrahın gerçeğe uygunluğu vergi incelemesi yoluyla yapılabilmektedir. Vergi Usul Kanunun 371. maddesinde yer alan pişmanlık ve ıslah müessesi, beyana dayalı vergilerde mükellefin durumunu bazı koşulların sağlanması kaydıyla uyuşmazlıkların idari aşamada çözümleme olanağı sağlamaktadır.

Vergi Usul Kanunun 359. maddesine göre, anılan kanunun 371. maddesindeki koşullara uygun olarak durumu ilgili makamlara pişmanlık dilekçesi ile bildirenler hakkında, kaçakçılık cezasının uygulanmayacağı belirtilmiştir. Dolayısıyla 371. maddede yer alan pişmanlık müessesinden yararlanma koşulları arasında yer alan ve vergi ziyaı cezası kesilmesini engelleyen "ödeme" koşulunun, kaçakçılık cezası açısından geçerli olup olmadığı konusu, halen üzerinde uzlaşılamayan bir konu durumundadır. Yine, mücbir sebeplerin var olması halinde pişmanlık müessesi için belirlenmiş sürelerin akıbeti de tartışmalı bir husustur.

$\mathrm{Bu}$ çerçevede; vergi ziyaı olmaksızın kaçakçılık fiillerinin işlenmesi durumunda pişmanlık müessesinin uygulanmamasının vergilemede eşitlik açısından değerlendirilmesi, matrahsız verilen beyannamelerin vergi ziyaına sebebiyet verilmediği gerekçesiyle pişmanlık hükümleri çerçevesinde kabul edilmemesinin ortaya çıkarabileceği sonuçlar da üzerinde durulmaya değer özellikler taşımaktadır.

Çalışmamızda, bu konular vergi hukuku ve ceza hukuku normları dikkate alınarak değerlendirilmekte ve ortaya konulan sorunlara yönelik görüş ve önerilerde bulunulmaktadır.

\section{Giriş}

Pişmanlık, Vergi Usul Kanununda yer alan vergi ziyaı ve/veya vergi kaçakçılığı cezasını gerektiren fiilleri işleyen ve bu nedenle idari ve/veya adli yaptırıma muhatap olabilecek kişilerin bu yaptırımlardan kurtulmalarını sağlayan bir kurumdur.

Vergi Usul Kanununa 1950 yılından itibaren getirilen ve çeşitli değişikliklere uğrayan pişmanlık ve ıslah, beyana dayalı vergilerde yükümlü tarafından pişmanlık dilekçesi verilmesi ve kanunda belirtilen diğer şartların yerine getirilmesi durumunda adli ve idari yaptırımlara muhatap olmamalarını sağlar.

Vergi Usul Kanunu'nun 359. maddesinde "371. maddedeki pişmanlık şartlarına uygun olarak durumu ilgili makamlara bildirenler hakkında bu madde hükmü uygulanmaz" hükmü yer almaktadır. Buradan da anlaşılacağı üzere, pişmanlık cezayı hafifletici bir sebep olarak değil; ortadan kaldıran bir kurum olarak düzenlenmiştir. Suçun varlığı devam etmesine rağmen kanunda belirtilen şartların varlığı halinde yükümlü veya sorumluya ceza kesilmez. Her ne kadar birçok kaynakta ceza hukukunda faal nedamet ve ön ödeme kurumlarıyla karşılaştırılsa da, pişmanlık ve ıslah vergi hukukuna özgü ve vergi cezalarını ortadan kaldırmak suretiyle vergi sorunlarının idari aşamada çözümünü sağlayan bir yol olarak görülmelidir (Karakoç, 1997: 16).

Pişmanlık mükelleflere ceza muafiyeti gibi imkânlar sağlarken, idare açısından da tespiti belki de hiç mümkün olmayacak ya da çok geç tespit edilebilecek bir vergi 
kaybının bir an önce tahsilini sağlamaktadır. Pişmanlıktan yararlanma hali (Şenyüz, 2015: 315);

1)Vergi ziyaı kabahatine ilişkin cezanın kesilmesine engel olur,

2) Devlet bir an önce vergi alacağına kavuşmasını sağlar,

3) Pişmanlıktan yararlanılması idareyi ortaya çıkacak bazı tespit ve takip giderlerinden kurtarır.

Pişmanlık ve ıslah uygulaması ile ilgili olarak hükmün uygulamasında karşılaşılan bazı sorunlar mevcuttur. Pişmanlıkla verilen beyannamelerde zarar beyan edilmesi veya matrah gösterilmemesi, pişmanlıktan yararlanılması için vergi ziyaı koşulunun mutlak surette aranması, mücbir sebeplerin pişmanlık hakkına etkisi, beyanname ve ödemeye ilişkin şartların gerçekleşmemesi halinde kaçakçılık suçlarının durumu bu çalışmada ele alınacak sorunlardandır.

Pişmanlık ve ıslah kurumunun uygulaması ile ilgili olarak Vergi Usul Kanunu hükümlerinin yeterince netlik içermemesi dolayısıyla yaşanan tereddütler ve bunlara literatürdeki farklı yaklaşımlar ile yukarıda sıralanan sorunlara çözüm önerileri çalışmanın konusunu oluşturmaktadır.

\section{Pişmanlıktan Yararlanmak İçin Vergi Ziyaı Koşulunun Aranmasının Eşitlik ilkesi Açısından Değerlendirilmesi}

\subsection{Pişmanlıktan Yararlanma Şartları}

Pişmanlık müessesesini düzenleyen Vergi Usul Kanunun 371. maddesinde, beyana dayanan vergilerde "vergi ziyaı cezasını gerektiren fiilleri işleyen" mükelleflerle buna iştirak eden diğer kişilerin kanuna aykırı hareketlerini ilgili makamlara kendiliğinden dilekçe ile haber vermesi halinde, haklarında maddede belirtilen ve aşağıda sıralanan şartların da gerçekleşmesi halinde vergi ziyası cezası kesilmeyeceği belirtilmiştir.

1. Mükellefin keyfiyeti haber verdiği tarihten önce bir muhbir tarafından herhangi bir resmi makama dilekçe ile veya şifahi beyanı tutanakla tevsik etmek sureti ile haber verilen husus hakkında ihbarda bulunulmamış olması. (Dilekçe veya tutanağın resmi kayıtlara geçirilmiş olması şarttır)

2. Haber verme dilekçesinin yetkili memurlar tarafından mükellef nezdinde her hangi bir vergi incelemesine başlandığı veya olayın takdir komisyonuna intikal ettirildiği günden evvel (kaçakçılık suçu teşkil eden fiillerin işlendiğinin tespitinden önce) verilmiş ve resmi kayıtlara geçirilmiş olması.

3. Hiç verilmemiş olan vergi beyannamelerinin mükellefin haber verme dilekçesinin verildiği tarihten başlayarak on beş gün içinde tevdi olunması

4. Eksik veya yanlış yapılan vergi beyanının mükellefin keyfiyeti haber verme tarihinden başlayarak on beş gün içinde tamamlanması veya düzeltilmesi

5. Mükellefçe haber verilen ve ödeme süresi geçmiş bulunan vergilerin, ödemenin geciktiği her ya ve kesri için 6183 sayılı Kanunun 51. maddesinde belirtilen 
nispette uygulanacak gecikme zammı oranında bir zamla birlikte haber verme tarihinden başlayarak on beş gün içinde ödenmesi

Ayrıca; VUK'nun 359. maddesinde yer alan kaçakçılık fiillerini işleyenlerin 371. maddede düzenlenen pişmanlık hükümlerinden yararlanmaları halinde haklarında 359. maddede yer alan hürriyeti bağlayıcı cezalar yönünden işlem yapılmayacağı hükme bağlanmıştır.

\subsection{Fiillerin Vergi Ziyaı Cezasını Gerektirmesi}

Pişmanlık hükümlerini düzenleyen madde metnine bakıldığında, kanunun lafzı açıkça "vergi ziyaı cezasını gerektiren fiilleri işleyen mükellefleri" kapsadığı görülecektir. Yani pişmanlık hükümlerinden yararlanabilmenin öncelikli koşulu belirli fillerle vergi ziyaına sebebiyet vermektir. Bu itibarla, vergi kanunlarına aykırı olduğu halde fiilin sonucunda vergi ziyaı ortaya çıkmıyorsa mükellefin pişmanlık talebinde bulunması mümkün olmayacaktır.

Pişmanlık hükümlerinden yararlanılmasının ön koşulunun vergi ziyaına sebebiyet vermek olmasına kaçakçılık suçları açısından bakılacak olursa ortaya ciddi bir sorun çıkmaktadır. Şöyle ki; Vergi Usul Kanunun 359. maddesinde yer alan kaçakçılık fiillerinin işlendiğinden bahsedebilmek için mutlak surette vergi ziyaının oluşması şartı aranmamaktadır.

Ceza hukukunda illiyet bağının kurulabilmesi için hareket ve neticenin gerçekleşmiş olması gerekmektedir. Bu nedenle kaçakçılık suçları açısından suçun maddi unsurunda VUK'nın 359. maddesinde belirtilen hareketlerden sadece birisinin yapılmış olması suçun oluşması açısından yeterlidir. Kaçakçııı suçu bu anlamda hareket suçu, tehlike suçu ve şekli suç niteliği taşımakta, ayrıca vergi ziyaının meydana gelmiş olması aranmamaktadır(Erman, 1988: 32; Karakoç, 2007: 471). Zaten maddedeki bazı fiillerle vergi ziyaına sebebiyet verme imkân ve ihtimali de bulunmamaktadır (Demirci, 2009: 67). (Maliye Bakanlığı ile anlaşması olmadığı halde belge basanların kaçakçılık fiilini işlemiş sayılmaları) Bu durumun farklı bir örneği olarak VUK 359. maddenin (a) fıkrası 1 . bendinde yer alan defterlere kaydı gereken hesap ve işlemlerin vergi matrahını azalması sonucunu doğuracak tarzda tamamen veya kısmen başka defter, belge veya diğer kayıt ortamlarına kaydedilmesi" suçunda vergi matrahını azaltıcı sonucu dolayısıyla bir zarar suçundan bahsedilmekte ve vergi ziyaı aranmaktadır. Suçta belirtilen netice gerçekleşmemiş ise suç tamamlanmamış olur. Bu nedenle bir suçtan bahsedilebilmesi için maddi unsurunun yani illiyet bağının ortaya konulması gerekmektedir. Bu itibarla kaçakçılık suçunun maddi unsuru vergi ziyaı değil, VUK 359. maddede sayılan fiillerin işlenip tamamlanması olarak tanımlanabilir.

Maddede belirtilen fiillerle vergi ziyaına sebebiyet verilmesi sadece vergi ziyaı cezasının 3 kat kesilmesi için gerekli olup, hürriyeti bağlayıcı cezalar bakımından vergi ziyaı bir ön koşul niteliği taşımamaktadır. Ancak pişmanlık hükümlerinden yararlanmanın ön koşulu olarak vergi ziyaına sebebiyet verme şartı gerekliliği madde lafzından anlaşılmaktır. Zira 359. maddede "371. madde hükmündeki pişmanlık şartlarına uygun olarak durumu ilgili makamlara bildirenler hakkında bu madde hükmü uygulanmaz" biçiminde yer alan düzenlemeyi açarsak pişmanlık şartlarına 
bakılması gerekecektir. Pişmanlık şartlarına bakıldığında ise, madde metninde belirtilen şartların sağlanmasından evvel, beyana dayanan vergilerde vergi ziyaı cezası gerektiren fiillerin işlenmiş olması veya buna iştirak edilmiş olması halinin varlığının arandığı görülmektedir.

Pişmanlık müessesi vergi suçu işleyenlerin gizli kalan kanuna aykırı bazı fiillerin belirli şartlarla cezalandırılmaktan vazgeçilmesini amaçlamaktadır. Böylece, gizlenen suçlar ve vergi alacağı ortaya çıkarılmakta, vergi ahlakı açısından ise zihni bir alıştırma fırsatı oluşturulmaktadır (Kocahanoğlu, 1985: 123).

Kaçakçılık suçu işleyerek aynı zamanda vergi ziyaına sebebiyet verenlerin, pişmanlık hükümlerinden yararlanarak, hem 344. maddede belirtilen 3 kat vergi ziyaı cezasından hem de 359. maddede yer alan hürriyeti bağlayıcı cezalardan kurtulmaları mümkün iken; vergi ziyaına sebebiyet vermeyenlerin ise pişmanlık hükümlerinden yararlanmaları mümkün olmadığından her koşulda hürriyeti bağlayıcı cezaya tabi olacağı sonucuna ulaşılmaktadır.

\subsection{Ortaya Çıkan Eşitsizlik Hali}

Bu noktada; kaçakçılık suçunun oluşumu için vergi ziyaı sonucu aranmazken, kaçakçııı fiili dolayısıyla kesilecek vergi ziyaı cezası ve hürriyeti bağlayıcı cezanın ortadan kaldırılması için yararlanılacak "pişmanlık" müessesi için vergi ziyaı sonucunun aranıyor olması hem vergilemede eşitlik ilkesine aykırı hem de pişmanlık müessesinin amacına ters düşen bir durumdur.

Özellikle vergi kaçakçılığı suçları içinde yer alan sahte ve muhteviyatı itibariyle yanıltıcı belge düzenleme ve kullanma fiilleri belli bir organizasyon dahilinde işlenen ve ekonomik çıkar elde edilen suçlar kapsamındadır. Pişmanlık hükümlerinden yararlanmanın vergi ziyaına sebebiyet verme şartına bağlanması bu suçların takibini de güçleştirmektedir.

Konuyu uygulama yönüyle bir örnek ile açıklayacak olursak; sahte belge düzenleyicisi durumunda olan ve birbiriyle bağlantılı şirketler grubu şeklinde organize olmuş bir yapıdan aldığı belgeleri kullanan, yıl boyunca indirim konusu yaparak KDV beyannamelerine dahil eden mükellef, devreden KDV tutarının indirilebilir KDV tutarından fazla olması durumunda yıl içinde bu faturaları kullanmış olması dolayısıyla "pişman" olsa da pişmanlık kurumundan yararlanmak istemesi halinde söz konusu şirketlerin tespiti mümkün olmayacaktır. Çünkü mükellef kullanmış olduğu sahte faturaları indirim konusu yapmasa dahi vergi ziyaına sebebiyet vermediği gerekçesiyle pişmanlık hükümlerinden yararlanamayacak, bu nedenle kaçakçılık fiili dolayısıyla 3 kat vergi ziyaı cezası ve hapis cezasına muhatap olmamak için vergi ziyaı cezasının ortaya çıkmasını bekleyecek veya Kurumlar vergisi beyannamesinde ilave matrah ve ve vergi beyan ederek pişmanlık hükümlerinden yararlanacaktır.

Burada vurgulamak istediğimiz nokta, vergi ziyaı oluşmasının kaçakçılık suçlarının ön koşulu olmadığı halde kanunda yer alan düzenleme nedeniyle pişmanlık hükümlerinden yararlanmanın koşulu haline getirilmiş olmasıdır. Bu durum eşitlik ilkesine aykırılık içermektedir. 
Pişmanlık hükümlerinden yararlanmanın vergi ziyaı koşuluna bağlı olmaktan çıkarılması müessesenin daha etkin şekilde kullanımını sağlayacak ve özellikle kaçakçılık suçları açısından yaşanan çelişkili durumun önüne geçilerek müessesenin daha etkin olması sağlanabilecektir.

\section{Zarar Beyan Edilen Veya Matrahsız Verilen Beyannamelerin Pişmanlık Hükümlerinden Yararlanamaması Durumunun Değerlendirilmesi}

Uygulamada mükelleflerin vergiye tabi bir matrah beyan etmeleri mümkün olduğu gibi, beyannamelerini matrahsız vermeleri veya kanunda yer alan mahsuplar dolayısıyla ödenecek vergilerinin bulunmaması da mümkündür. Söz konusu beyannameler kanuni süresi içinde verilmiş olabileceği gibi kanuni süresinden sonra da verilmiş olabilir. Kanuni süresi içinde ya da süresinden sonra verilmiş olsa da idare pişmanlık talebiyle verilmiş bu durumdaki beyannamelere ilişkin pişmanlık taleplerini reddetmekte ve buna göre işlem yapmaktadır.

\section{1. İdarenin Görüşü}

Konuya ilişkin olarak şimdiye dek idarenin izlemiş olduğu yol; Vergi Daireleri İşlem Yönergesi 39/5-c uyarınca "Pişmanlık talebiyle verilen beyannamede zarar beyanı veya mahsuplar gibi nedenlerle ödenecek verginin bulunmaması veya matraha ilişkin bilgilerin olmaması ya da pişmanlık ve ıslah hükümlerinin uygulanmasına engel bir durumun mevcut olması hallerinde pişmanlık talebi kabul edilmez. Beyanname kanuni süreden sonra verilen beyanname olarak işleme tabi tutulmak üzere tahakkuk fişi düzenlenerek diğer tarh işlemleri masasına verilir." şeklindedir.

Yine 238 Seri No'lu Vergi Usul Kanunu Genel Tebliğinin “D-2 Kanuni Süresi Içinde Verilmeyen Beyannamenin Daha Sonra Pişmanlık Hükümleri Uygulanması Talebiyle Verilmesi" başlıklı bölümünde;"....Pişmanlık talebiyle verilen beyannamede zarar beyanı veya mahsuplar gibi nedenlerle ödenecek verginin bulunmaması halinde, pişmanlık talebi kabul edilmeyecek ve bu beyannameler için de yalnızca birinci derece iki kat usulsüzlük cezası kesilecektir. Ancak, gerek görülmesi halinde, bu mükellefler nezdinde inceleme yaptırılabilecektir" ifadesine yer vermek suretiyle idare kanuni süresinden sonra verilen beyannamelere ilişkin görüşünü ortaya koymuştur.

\subsection{Danıştay'ın Görüşü}

Konuya ilişkin olarak Danıştay ise farklı görüştedir. Birçok karar örneğinde zarar beyan edilen ya da matrah gösterilmeyen beyannamelerin pişmanlıkla talebiyle verilmesinde kanuna aykırı bir durum olmadığı ve mükelleflerin VUK 371 . madde hükmünden yararlanması gerektiği belirtilmektedir.

Danıştay.7.Dairesi, 17.04.1986 Tarih, E.1984/1245,K.1986/1295 sayılı kararında; 
"...Öte yandan matrah göstererek beyanname veren yükümlü ile zarar beyan eden veya matrahsız beyanda bulunan yükümlü arasında herhangi bir fark yoktur. Zira verilecek beyannamelerin, bu üç halden herhangi birini kapsaması kanunen mümkün ve geçerlidir. Önemli olan husus beyannamede gösterilen durumun gerçeğe uygun olmasıdır. Ayrıca zamanında beyanname verdiği halde zarar beyan eden veya vergiye tabi matrah bulunmadığı yolunda beyanda bulunan yükümlüler hakkında sırf bu nedenle res'en takdir hükümleri uygulandığı unutulmamalıdır. Aynı durumda olmakla birlikte zamanından sonra verilmesine rağmen pişmanlık hükümleri uyarınca kanun koyucu tarafından zamanında verilmiş sayılan matrahsız beyannameler için res'en takdire gitmek, kanun koyucunun sonrada pişmanlıkla verilen beyannamelerin zamanında verilmiş sayılması yolundaki amacına da ters düşer"

Danıştay 4.Dairesi, 07.11.1974 Tarih, E.1974/854, K.1974/3810 Sayılı Kararında;

“...Amaç pişman olan, nedamet duyan yükümlüleri himaye etmektir. Kanunda pişmanlık hükümlerinden sadece kazançlı beyanname veren yükümlülerin faydalanacağına dair bir hüküm de yoktur. Pişman olma ve nedamet duyma yükümlülerin sübjektif durumlarını gösterdiğinden, kazançlı beyanname veren yükümlü ile zarar beyan eden veya asgari geçim indiriminin altında gelir elde ettiğini bildiren yükümlü arasında herhangi bir fark yoktur. Aynı sübjektif durumda olan yükümlülerin aynı hükümlerden faydalanması, kanun önünde eşitlik ilkesinin gereğidir."

Danıştay 7.Dairesi, 09.02.1983 Tarih, E.1981/2542, K.1983/217 Sayılı Kararında ise;

"Maddenin amacı pişmanlık duyan yükümlüleri korumak olup yasada pişmanlık hükümlerinden sadece vergi beyan eden yükümlülerin yararlanacağına dair bir hüküm yoktur. Pişman olma yükümlülerin sübjektif durumlarını gösterdiğinden vergi beyan eden yükümlü ile vergiye tabi muamelesi olmadığını beyan eden yükümlü arasında bir fark bulunmamaktadır."

şeklinde hüküm vermiştir.

\subsection{Konunun Değerlendirilmesi}

Görüldüğü gibi, vergi idaresi müstakar hale gelmiş yargı kararlarına rağmen kendi görüşünde ısrar etmekte, pişmanlık talebi ile verilen beyannamelerde;

- Zarar beyan edilmesi,

-isstisna uygulamaları nedeniyle matrah beyan edilmemesi,

- Faaliyetsiz oluşu nedeniyle matrah beyan edilmemesi,

-Indirimler nedeniyle ödenecek herhangi bir vergi beyan edilmemesi hallerinde, mükellefler veya vergi sorumluları pişmanlık ve ıslah hükümlerinden yararlandırılmamakta ve olay takdir komisyonuna ve gerektiğinde vergi incelemesine sevk edilmek suretiyle, dönem matrahının re'sen belirlenmesi yoluna gidilmektedir. Maliye Bakanlığına göre, pişmanlık ve ıslah hükümleri sadece vergi ziyaı doğmasını gerektirecek durumlarda uygulanmaktadır. 
Pratikte yaşanan en önemli sorunlardan birisi vergi kanunlarına aykırı davranmakla birlikte zarar azaltımı, mahsup, indirim gibi nedenlerle işlenen fiillerin yasaya uygun hale getirilmesi sonucu vergi ziyaı oluşmaması nedeniyle mükelleflerin pişmanlık müessesinden yararlanamamalarıdır. Her ne kadar Danıştay'ın görüşü aksi yönde olsa da matrahsız verilen beyannamelerin vergi ziyaı oluşmadığı gerekçesiyle pişmanlık hükümlerinden yararlanamayacağı konusunda idarenin görüşü açık ve kesin olup bu husus 238 No'lu VUK Genel Tebliği ile de belirtilmiştir.

Söz konusu genel tebliğde pişmanlıkla verilen beyannameler ile zarar beyanı veya mahsuplar nedeniyle ödenecek verginin bulunmaması halinde pişmanlık talebinin kabul edilmeyeceği ve gerek görülmesi halinde mükellefin incelemeye sevk edileceği belirtilmiştir. Fakat bu düzenleme aynı fiili işleyerek vergi ziyaına yol açan ve açmayan mükellefler arasında eşitlik ilkesini zedeleyici sonuçlar ortaya çıkmasına sebep olmuştur. Ayrıca, pişmanlık hükümlerinden yararlanmanın vergi ziyaı cezasına sebebiyet verme şartına dayandırılması, idarenin vergi kanunlarına aykırı fiilleri öğrenmesine engel olduğundan, bu bilgiler dolayısıyla elde edilebilecek kamusal yarar göz ardı edilmektedir.

Pişmanlık müessesinin hukuki anlamının sorgulanması açısından ortaya çıkan bir diğer sorun ise beyannamenin kanuni süresi içinde veya kanuni süresinden sonra matrah artırıcı ya da vergi ödemesine yol açacak şekilde verilmesi/ matrah azaltıcı, vergi ödemesine yol açmayacak şekilde verilmesi durumlarıdır.

Konuyu bir örnek ile açıklayacak olursak; yüklü miktarda devreden KDV tutarına sahip A şirketi Eylül 2015 KDV beyannamesinde yer alan bazı faturaları beyannamesinden çıkartmak istemesi ve gerekli düzeltme işlemlerini Kasım 2015 döneminde yapması halinde e-beyanname sisteminde "kanuni süresinden sonra" ve "düzeltme" beyannamesi seçeneklerini tercih etmek suretiyle vergi ziyaı cezasına muhatap olmayacaktır. Bunun nedeni şirketin vergi ödemesi bulunmaması nedeniyle sistemin pişmanlık seçeneğini mükellefe bir yol olarak sunmamasıdır. Mükellefin devreden KDV tutarının olmaması durumunda ise, e-beyanname sisteminde "kanuni süresinden sonra" ve "pişmanlık" talebiyle beyanname verilmektedir. İşlem kanuni süre içinde yapılmak istenirse ilk durumdaki mükellefin "pişmanlık" seçeneğini tercih etmesi mümkün olmamaktadır. Bu durumda en akılcı yol kanuni sürenin geçmesini bekleyerek "kanuni süresinden sonra" ve "düzeltme" seçeneklerini tercih etmektir.

Beyan süresi içinde çeşitli nedenlerden dolayı beyanname verilmemesi durumunda verilecek beyanname için yine ödeme çıkıp çıkmadığı önem taşımaktadır. Sistem aynı şekilde işlemektedir.

Burada karşımıza idarenin pişmanlık ve ıslah kurumuna bakış açısı çıkmaktadır. Zira bu işleyiş Türk vergi sisteminde pişmanlık kurumunun mükellefi "ıslah" amacının "tahsilat" amacının gerisinde kaldığını göstermektedir.

Bu noktada pişmanlık kurumunun mali amacı ve ceza hukuku amacına kısaca değinilmesinde yarar bulunmaktadır.

Ceza hukuku amacı açısından; genel itibariyle vergi yasalarına aykırı olarak işlenen fiil veya fiillerin, fail tarafından telafi edilmesi esas alınmaktadır. Bu noktada 
devletin mahrum kaldığı vergi gelirinin ortaya çıkarılması ve ödenmesi karşılığından mükelleflere ceza muafiyeti getirilmektedir(Yıldırım, 2013: 54). Telafi, ceza ile amaçlananı karşılayabilmekte ve bir yaptırım aracı olarak yeterli olabilmektedir (telafi amacı) (çeviren Yıldırım, 2013: 54).

Ceza politikası açısından, pişmanlık ve ıslah kurumunun görevi, kaçırılmış olan vergilerin ceza muafiyeti vaadiyle gönüllü olarak ödenmesi yönünde bir teşvik etkisi oluşturmaktır. Yani bu düzenlemeyle, ceza ödememe fırsatını sunmak suretiyle faili, suçtan vazgeçmeye teşvik etmek söz konusudur. Özetle öncelikli amaç cezadan muafiyet vaad edilerek onun üzerine teşvik etkisi oluşturulması yani teşvik amacıdır. Faile sağlanan avantajlar arttıkça teşvikin gücü de o denli artacaktır. Daha sonra ise, failin neden olduğu sonucu yani zararı telafi etmesi amaçlanmaktadır (Yıldırım, 2013: 51).

Pişmanlık müessesinin mali amacı ise; cezadan muafiyet için kaçırılan verginin ödenmesini şart koştuğu düşünülürse, daha fazla vergi geliri elde etmek olarak karşımıza çıkmaktadır. Devlete yüklenen sosyal ve ekonomik ödevlerin sayıca fazlalaşması karşısında yeni vergi kaynaklarının ortaya çıkarılması ihtiyacı da artmaktadır. Bu nedenle pişmanlık ve ıslahın sağlayacağı ilave gelirlerin hatırına bundan yararlanacak vergi suçlularının kayrılmasına göz yumulabilir (Dönmez, 2009: 21).

Bu noktada mali amaç ile ceza hukuku amacının konuya farklı açılardan yaklaştığı görülmektedir. Mali amaç pişmanlık kurumunun başarısını tahsil edilecek gelir ile ölçerken, ceza hukuku amacında failin işlemiş olduğu fiilden vazgeçmesi ve bunu telafi etmesi ön plandadır.

Türk vergi hukukunda pişmanlık müessesinin işleyişine bakıldığında da VUK 371. madde hükmünün mali amaca daha çok hizmet ettiği sonucuna varılabilir. Nitekim, 371. maddede, verginin geç de olsa tahsil edilmesi idare ve mükellef ilişkilerinin uyuşmazlığa yer verilmeden sürdürülmesi temel amaç olarak öne çıkmaktadır.

Toplum nezdinde oluşan algı ise mükellefin pişmanlık kurumundan yararlanarak "ıslah" olmasından ziyade devlet hazinesine gelir sağlanmasına önem verildiğidir. Matrahsız beyannamelerin pişmanlık müessesinden yararlanamıyor oluşu düşünülecek olursa; bu algının çok da yersiz olmadığı anlaşılmaktadır.

Kanundaki ifade "...vergi ziyaı cezasını gerektiren fiilleri işleyen mükelleflerle bunların işlenişine iştirak eden diğer kişilerin kanuna aykırı hareketlerini ilgili makamlara kendiliğinden dilekçe verilmesi" şeklinde olup, kanun vergi ziyaı cezası gerektiren fiillerin işlenmesini ve bunu belirtilen şartlara uygun olarak haber verilmesini esas almıştır. Kanun metninde "zarar beyanı veya mahsuplar dolayısıyla ödenecek vergi bulunmazsa pişmanlık hükümlerinden yararlanılmaz" şeklinde bir ifade bulunmamaktadır. Kanunda yer almayan bir düzenlemenin genel tebliğ ile yapılması kanunilik ilkesine ters düşmektedir. Kanunda dahi yer almayan bu uygulamanın bir an önce yargı kararları doğrultusunda düzeltilerek tartışmaya yer bırakmayacak biçimde uygulanması gerektiği kanaatindeyiz. 


\section{Mücbir Sebeplerin Pişmanlık Şartlarına Etkisi}

Vergi Usul Kanunun 15. maddesine göre aynı kanunun 13. maddesinde yazılı mücbir sebeplerden herhangi birinin bulunması halinde söz konusu mücbir sebep ortadan kalkıncaya kadar süreler işlemeyecektir. Böyle bir durumda VUK 15. madde uyarınca tarh zamanaşımı işlemeyen süreler kadar uzayacaktır (Doğrusöz,2003: 220).

Kanunda mücbir sebep halleri ve bunların sürelere etkisi belirtilmiş ancak mücbir sebep tanımı yapılmamıştır. Mücbir sebep, gerçek dünyada meydana gelen bir olayın hukuk aleminde söz konusu olan bir ödev, yükümlülük veya borcun yerine getirilmesini ya da bir hakkın kullanılmasını geçici olarak durdurmasıdır (Yerlikaya, 2012: 44).

Vergi hukuku açısından mücbir sebep ise; vergi mükellef ve sorumluları ile ceza muhataplarının isteseler bile kendi çabalarıyla ve iradeleriyle dahi oluşunu ve sonuçlarını engelleyemeyecekleri doğal veya yapay durumlar olarak açıklanabilir.

Vergi Usul Kanunun 13. maddesinde mücbir sebepler;

1. Vergi ödevlerinden herhangi birinin yerine getirilmesine engel olacak derecede ağır kaza, ağır hastalık ve tutukluluk

2. Vergi ödevlerinin yerine getirilmesine engel olacak yangın, yer sarsıntısı ve su basması gibi afetler

3. Kişinin iradesi dışında vukua gelen mecburi gaybubetler

4. Sahibinin iradesi dışındaki sebepler dolayısıyla defter ve vesikaların elden çıkmış bulunması gibi haller olarak sıralanmıştır.

Mükellef veya ceza muhatabı yasalarca belirtilen vergi ödevlerinden herhangi birisini yerine getirmesine engel olacak şekilde Vergi Usul Kanunu 13. maddedeki hallerden biriyle karşı karşıya kalmış ise mücbir sebep hali var demektir ve kanunda buna ilişkin olarak belirtilen etki ve sonuçlardan yararlanacağı açıktır.

Burada pişmanlık müessesesi ile mücbir sebepler arasındaki çelişkiye düşülen nokta; mücbir sebeplerin, sürelere etkisi noktasında ortaya çıkmaktadır.

Ilk olarak, Vergi Usul Kanunun 13. maddesinde sıralanan mücbir sebep hallerine bakıldığında bunların vergi ödevlerinin yerine getirilmesiyle ilgili olduğu yorumu yapılmakta ve pişmanlığın bir vergi ödevi olup olmadı̆̆ı hususu gündeme gelmektedir.

İkinci olarak, Vergi Usul Kanunu 15. maddede yer alan " 13. maddede yer alan mücbir sebeplerden herhangi birinin bulunması halinde bu sebep ortadan kalkıncaya kadar süreler işlemez" hükmü, vergi ödevlerine ilişkin süreleri mi kapsamaktadır yoksa vergi ödevleri dışında kalan süreler için de bu madde hükmü uygulanacak mıdır?

Öncelikle Vergi Usul Kanunu 15. maddede yer alan sürelere ilişkin hükmün, mücbir sebep dolayısıyla sürelerin duracağını belirten genel bir hüküm olduğunu, burada mücbir sebeplerin sadece "vergi ödevleriyle ilgili olanları değil, bütün süreleri" etkilediğini belirtmek gerekir. VUK madde 13 'de yer alan "vergileme ile ilgili ödevlerin yerine getirilmesine engel olunacak derecede" ifadesi, mücbir sebeplerin uygulama alanını daraltmaya yönelik bir ifade olmayıp, mücbir sebep olarak belirtilen durumların, mücbir sebep sayılmalarına ilişkin objektif bir ölçü ortaya koymuştur. Kaldı ki, "vergi 
ödevlerinden herhangi birinin yerine getirilmesine engel olacak derecede" ifadesi,13. maddede sayılan mücbir sebep hallerinin tümü için kullanılmamıştır (Taş, 1997:156).

Bununla birlikte yaşanan tereddüdün asıl nedeni pişmanlık talebinde bulunma ve sonrasında yaşanan sürecin mükellef açısından bir hak mı yoksa bir vergi ödevi mi olduğu konusundadır.

Gerek yargı kararları, gerekse konu hakkındaki literatür incelendiğinde; Vergi Usul Kanunu 13. maddesinde "vergi ödevi" ifadesi yer aldığı için, mükellef hakkı olarak nitelendirilen dava açma, uzlaşma, pişmanlık ile ilgili olarak; "ağır kaza", "ağır hastalık", tutukluluk" hallerinin hukuki bir etki ve sonuç doğurmayacağını ileri süren bir görüşün yanı sıra, mücbir sebep halinin vergi ödevleri ile sınırlı olmayıp mükellef haklarını da kapsadığını savunan yargı kararları vardır.

Konuya pişmanlık ekseninde yaklaşılacak olursak, her ne kadar pişmanlık bir vergi ödevi değil, mükellef hakkı gibi nitelendiriliyor olsa da, pişmanlık talebinde bulunulduğu anda, bu tarihten itibaren 15 gün içinde beyanname verme ve ödeme yükümlülüğünün üstlenilmesi bunu bir ödev haline getirmekte ve Vergi Usul Kanunu 15. maddede yer alan hükmün tüm sürelere etki edeceği de göz önüne alındığında mücbir sebeplerin varlığının pişmanlıkla ilgili süreleri de etkileyeceği sonucuna ulaşılmaktadır.

Kişisel görüşümüz, mücbir sebeplerin pişmanlık ile ilgili 15 günlük süreye durdurucu etki yapacağı yönündedir.

\section{Beyanname ve Ödemeye İlişkin Şartların Gerçekleşmemesi Halinde Kaçakçılık Suçu}

\subsection{Genel Açıklama}

Pişmanlık müessesinin kaçakçılık suçları açısından incelemesi yapılırken hem VUK 359. maddede yer alan kaçakçılık suçlarının hem de pişmanlıktan yararlanma şartlarının kademeli olarak incelenmesi ve madde hükümlerinin bu şekilde yorumlanması yaşanan yorum farklılıklarının anlaşılması açısından daha yararlı olacaktır.

Öncelikle VUK 359. maddesinde yer alan kaçakçılık suçlarının vergi ziyaı ile ilişkisi ve vergi suçunun oluşumu noktasında vergi ziyaı ile kaçakçılık sayılan fiiller arasında illiyet bağı kısaca açıklanacaktır. Zira bu durum pişmanlık kurumundan yararlanma bağlamında VUK 371. maddenin yorumlanması noktasında önem taşımaktadır. Başka bir ifadeyle, mükellefin kanuna aykırı hareketinin vergi ziyaı cezasını gerektirmiyor oluşu, pişmanlık kurumundan yararlanma koşullarını farklılaştırmaktadır (Somuncu\&Değirmendereli, 2015:74).

VUK 341. maddesinde yer alan hüküm doğrultusunda vergi ziyaı "Mükellefin veya sorumlunun, vergilendirme ile ödevlerini zamanında yerine getirmemesi veya eksik yerine getirmesi yüzünden verginin zamanında tahakkuk ettirilmemesini veya eksik tahakkuk ettirilmesi" olarak tanımlanmıştır. Aynı madde hükmü çerçevesinde "Şahsi, medeni haller veya aile durumu hakkında gerçeğe aykırı beyanlar ile sair suretlerle 
verginin noksan tahakkuk ettirilmesine veya haksı yere geri verilmesine sebebiyet vermek de vergi ziyaı hükmündedir"

Dolayısıyla bir mükellefin kanuna aykırı hareketi;

-Sadece vergi ziyaı cezasını gerektirebilir,

-Vergi ziyaına kaçakçılık cezasını gerektiren bir ya da birden fazla fiille sebep olunmuş olabilir. Bu halde mükellefe 3 kat vergi ziyaı cezası kesilmesi ve ayrıca hakkında kamu davası açılması söz konusu olabilir.

-Vergi ziyaı cezası gerektirmeyen ancak sadece kaçakçılık cezasını gerektiren bir ya da birden çok fiil dolayısıyla kamu davası açılması gerekebilir.

Pişmanlık müessesinin düzenlendiği VUK 371. madde hükmü "Beyana dayanan vergilerde vergi ziyaı cezasını gerektiren fiilleri işleyen mükellefler..." ifadesiyle başlamaktadır. Kanun koyucu burada mutlaka fiilin somut olarak vergi ziyaı sonucunu doğurmasını amaçlamakta mı yoksa vergi ziyaı ortaya çıkarma olasılığı dahi yeterli midir? Soruyu başka şekilde sorarsak; burada ifade edilen "vergi ziyaı", somut vergi ziyaını mı, yoksa potansiyel vergi ziyaını mı ifade etmektedir?

Bu çerçevede VUK 359. madde a, b, c bentlerinde yer alan suçlar kısaca incelenecek ve bu fiiller ile vergi ziyaı ilişkisi sonucu pişmanlık hükümlerinden yararlanma durumu tartışılacaktır.

\subsection{Kaçakçılık Fiilleri Bağlamında Pişmanlık}

VUK 359/a alt bendinde yer alan suçlar:

Vergi kanunlarına göre tutulan veya düzenlenen ve saklama ve ibraz mecburiyeti bulunan;

1) Defter ve kayıtlarda ve hesap ve muhasebe hileleri yapanlar, gerçek olmayan veya kayda konu işlemlerle ilgisi bulunmayan kişiler adına hesap açanlar veya defterlere kaydı gereken hesap ve işlemleri vergi matrahının azalması sonucunu doğuracak şekilde tamamen veya kısmen başka defter, belge veya diğer kayıt ortamlarına kaydedenler

2) Defter kayıt ve belgeleri tahrif edenler veya gizleyenler veya muhteviyatı itibariyle yanıltıcı belge kullananlar,

VUK 359/b alt bendinde yer alan suçlar:

Vergi kanunları uyarınca tutulan veya düzenlenen ve saklama ve ibraz mecburiyeti bulunan defter, kayit ve belgeleri yok edenler veya defter sahifelerini yok ederek yerine başka yapraklar koyanlar veya hiç yaprak koymayanlar veya belgelerin asıl veya suretlerini tamamen veya kısmen sahte olarak düzenleyenler veya bu belgeleri kullananlar,

VUK 359/c alt bendinde yer alan suçlar: 
Bu Kanun hükümlerine göre ancak Maliye Bakanlığı ile anlaşması bulunan kişilerin basabileceği belgeleri, Bakanlık ile anlaşması olmadığı halde basanlar veya bilerek kullananlar

Vergi ziyaına bu fiillerden herhangi biriyle sebebiyet verilmesi halinde vergi ziyaı cezasının 3 kat uygulanacağı VUK 344. maddede yer almakla birlikte, söz konusu fiilleri işleyenler alt sınırı 18 ay üst sınırı 5 yıl olmak üzere hapis cezası ile karşı karşıya kalmaktadır.

Pişmanlık müessesenin kaçakçılık suçlarıyla bağlantısı "VUK 359 maddede yer alan pişmanlık şartlarına uygun olarak durumu ilgili makamlara bildirenler hakkında bu madde hükmü uygulanmaz" hükmüdür.

Kaçakçılık suçu ile beraber vergi ziyaı kabahati de ortaya çıktığında pişmanlık hükümlerinden yararlanılabileceği noktasında tereddüt bulunmamaktadır. Kaçakçılık fiili işlenmesine rağmen vergi ziyaının ortaya çıkmadığı durumlarda pişmanlık hükümlerinden yararlanmak mümkün olacak mıdır?

VUK 359. maddesindeki fiiller incelendiği zaman her fiil ile mutlak surette vergi ziyaı sonucunun ortaya çıkmayacağı görülmektedir. Bunun en tipik örneği olarak 359/c bendinde yer alan Maliye Bakanlığı ile anlaşması olmayanların belge basımı fiili verilebilir. Bu noktada vergi kaçakçılığı fiilleri açısından mutlaka VUK 371. maddedeki şartlar mı aranacaktır yoksa, vergi ziyaına sebebiyet verilmese dahi kaçakçılık suçları için sadece ilgili makamlara bildirim koşulunun gerçekleşmiş olmasıyla pişmanlık hükümlerinden yararlanmak mümkün müdür?

Bir görüşe göre; 359. maddedeki bu hükümden yararlanabilmek için pişmanlık ve ıslahın tüm koşullarını aramamak ve sadece yapılan hukuka aykırı eylemi yetkili mercilere haber vermek yeterlidir (Donay, 2008: 211). Eğer 359. maddedeki herhangi bir suçu işleyen aynı zamanda vergi ziyaına da neden olmuşsa, bu durumda kendisi hakkında 371. maddedeki diğer koşulları yerine getirmek kaydı ile vergi ziyaı cezası da kesilmeyecektir. Kanımızca bu görüşün dayandığı temel VUK 359. maddede yer alan “ 371. maddedeki pişmanlık şartlarına uygun olarak durumu ilgili makamlara bildirenler hakkında bu madde hükümleri uygulanmaz" ifadesinde yer alan "durumu ilgili makamlara bildirenler" bölümüdür.

Aksi görüş ise, pişmanlık müessesesinin VUK 359. maddesindeki atıf gereği VUK'un 371.maddesinin uygun şartlar çerçevesinde uygulanması şeklinde olduğu yönündedir. Bunun anlamı VUK' nun 371. maddesindeki tüm şartların yerine getirilmesinin kurumdan yararlanııması bakımından aranacağıdır (Şenyüz, 2015:533).

\subsection{Konuya Illişkin Görüşler}

Görüldüğü üzere; bir fiil ile vergi ziyaına sebebiyet verilerek aynı zamanda kaçakçılık suçuna sebep olunması halinde; pişmanlık müessesinden yararlanılmasında tereddüt bulunmamaktadır. Ancak vergi ziyaı ortaya çıkarmayan kaçakçılık fiilleri için durum net değildir. Örneğin; Maliye Bakanlığı ile anlaşması olmadığı belge basanlar Vergi Usul Kanunu 359/c maddesi ile kaçakçılık suçu kapsamına alınmıştır. Anlaşması olmayan matbaada basılan belgeyi düzenleyen, kullanan mükellef vergi ziyaına yol 
açtığı zaman belge basım fiilini işleyen mükellefin de vergi ziyaına sebebiyet verdiği düşünülebilir mi? Yani vergi ziyaı tanımına bakılarak mükellefin şahsında bir vergi kaybı mı aranacak yoksa fiil dolayısıyla kişinin bağlantılı olduğu ve vergi ziyaına yol açan tüm öğeler bu kapsamda değerlendirilecek midir? Bu örnekte vergi ziyaı hangi aşamada aranacaktır?

Benzer bir durum sahte belge kullanımı ile ilgili olarak da söz konusu olmaktadır. Sahte belge kullanan iki mükelleften bir tanesinin zarar beyan etmesi dolayısıyla vergi ziyaı oluşmaması pişmanlık müessesinden yararlanmasına engel teşkil ederken, sahte belge kullanımı ile mevcut matrahını azaltan ve vergi ziyaına sebebiyet veren diğer mükellef pişmanlık hükümlerinden yararlanabilecektir. Oysa her iki mükellefte 359 . maddede yer alan sahte belge kullanma fiili ile kaçakçılık suçuna sebebiyet vermişlerdir.

Yaşanan tereddüt vergi ziyaının ortaya çıkmadığı durumda pişmanlık hükümlerinden yararlanmanın mümkün olup olmadığıdır. Kanun koyucunun işlenen fiilin sonucunun somut vergi ziyaı aradığı mı yoksa hangi aşamada vergi ziyaına sebebiyet verildiğini mi amaçladığı ya da vergi ziyaı oluşma olasılığını mı göz önünde bulundurduğu net değildir. (anlaşmalı matbaa örneğinde olduğu gibi)

Burada belirsizlik; VUK 371 madde metninde yer alan "vergi ziyaı cezasını gerektiren fiilleri işleyenler" ibaresinden kaynaklanmaktadır. Söz konusu ifadeyi sözel olarak yorumlayacak olursak; işlenen fiilin karşılığı olarak vergi ziyaı cezası verilmesi gerekmiyorsa pişmanlık kapsamına girmez anlamı çıktığı, konuya amaçsal olarak yaklaşıldığında, vergi ziyaı ortaya çıkmayan kaçakçılık fiillerinin de pişmanlık ve ıslah kapsamında olması gerektiği sonucuna ulaşılmaktadır (Kızılot\&Kızılot, 2010: 680).

Nitekim, pişmanlık kurumunun en önemli amaçlarından birisi de idarenin haberdar olmadığı belki de hiç haberinin olmayacağı bir suçun ortaya çıkmasını ve/veya verginin tahsilinin sağlanmasıdır. Vergi ziyaına sebebiyet veren fiillerin aynı zamanda kaçakçılık suçu da oluşturması durumunda pişmanlık yoluyla vergi ziyaı cezasından ve kaçakçılık suçları için öngörülen hapis cezasından kurtulmak mümkündür. Bu noktada, VUK 3. maddesinde yer alan "Vergi kanunları lafzı ve ruhu ile hüküm ifade eder" hükmü çerçevesinde yorumlanacak olursa; 371. maddede yer alan şartlara uygun şekilde bildirimde bulunanların, 359. madde kapsamındaki suçları bildirmiş olmaları dolayısıyla pişmanlık hükümlerinden yararlanmaları doğru olacaktır.

Yani işlenen kaçakçılık suçu aynı zamanda vergi ziyaı doğuruyorsa ve mükellef pişmanlıktan yararlanmak için başvurmuş fakat onun idari ve mali gereklerini yerine getirmemişse de ceza hukuku anlamında pişmanlıktan yararlanmaya devam edecektir (Şenyüz, 2015: 535).

Öte yandan vergi ziyaına sebebiyet vermeyen kaçakçılık suçları için pişmanlık müessesesinden yararlanılıp yararlanılmayacağı konusunda da literatürde farklı görüşler mevcuttur.

Bir görüşe göre; kaçakçılık suçu fiillerinden vergi ziyaını çıkarttığımızda geriye sadece kaçakçılık suçu kalmaktadır. Bu haliyle kaçakçıklık suçunun pişmanlık hükümlerinden yararlandırılmasında, pişmanlık müessesinden beklenen yarar sağlanmış olmaz. Aksi takdirde vergi ziyaına yol açmadan kaçakçılık suçu işlenir bu da 
her defasında pişmanlık kapsamında cezasız kalırsa hukukun ciddiyeti sorgulanır hale gelir (Şenyüz, 2015: 535).

$\mathrm{Bu}$ görüşe göre vergi ziyaına sebebiyet verilmeksizin işlenilen kaçakçılık suçlarının pişmanlık hükümlerinden yararlanması "kaçakçılık suçunu cezasız bırakmak" olarak yorumlanmaktadır.

Söz konusu görüşün dayandığı nokta yine pişmanlık ve ıslah hükümlerinden yararlanma şartlarıdır. Vergi ziyaı açısından pişmanlık hükümlerinden yararlanmanın şartları ile kaçakçılık suçu itibariyle pişmanlıktan yararlanmanın şartlarının tümüyle aynı olmadığı, kaçakçılık suçlarında vergi ziyaı meydana gelmemiş olsa bile pişmanlık ve ıslahtan yararlanılabileceği iddia edilebilirse de bunun kurumun amaç ve gerçekleriyle örtüşmediği belirtilmiştir (Şenyüz, 2015: 535).

Aynı yöndeki bir başka görüş ise vergi ziyaı gerektiren haller ile gerektirmeyen hallerde pişmanlık ve ıslahtan yararlanma koşullarının farklı şekillerde belirlenmesi gerektiğini savunmaktadır. Bu görüşe göre; vergi ziyaı bakımından şartları yerine getirmeyenlerin, kaçakçılık suçları bakımından pişmanlık ve ıslahtan yararlanabilmesi ya tamamen engellenmeli ya da en azından verginin aslını veya bir kısmını ödemesi halinde pişmanlıktan yararlanabilmesi şeklinde düzenleme yapılmalıdır (Somuncu \& Değirmendereli, 2015: 182).

Diğer görüşe göre; (Donay, 2008: 211) 371. madde hükmünün "vergi ziyaı" şartını aradığı açıktır. Ancak 359. maddedeki suçların oluşması için vergi ziyaının meydana gelmesi gerekli değildir. Böylece vergi ziyaı olmasa dahi 359. maddedeki suçların oluşumu halinde bunun ilgili makamlara haber verilmesi durumunda, kamu davası açılmayacak ve bu maddeyi ihlal edenlere ceza verilmeyecektir.

Söz konusu görüş 371. maddenin beyana dayanan vergilerde vergi ziyaından söz ettiğini belirtmekte ancak; 359/c bendinde yer alan Maliye Bakanlığı ile anlaşması olmaksızın belge basım suçu işleyenlerin beyanname vermelerinin söz konusu olmadığı belirtilmektedir. Dolayısıyla 359. maddede belirtilen pişmanlığa dair hükümlerden yararlanabilmek için pişmanlık hükümlerinin tüm şartlarını aramamanın sadece yapılan hukuka aykırı eylemin yetkili mercilere haber verilmesinin yeterli olacağı savunulmaktadır (Donay, 2008: 212).

Yine bu görüşe paralel bir başka yayında (Yaşin, 2010: 204); daha önce belirttiğimiz şekilde kanunun yorumlanma biçimine vurgu yapılmıştır. Söz konusu çalışmada, Vergi Usul Kanunu'nun 359. maddesindeki,“371. maddedeki pişmanlık şartlarına uygun olarak durumu ilgili makamlara bildirenler hakkında bu madde hükmü uygulanmaz." şeklindeki hükmün, bazı kimselerce, vergi ziyaına sebebiyet vermiş olsun olmasın Kanun'un 371. maddesinde 5 alt bent şeklinde sayılan bildirim şartlarına uygun olarak kaçakçılık suçlarına ilişkin fiillerini ilgili makamlara bildiren tüm kişiler hakkında uygulanabilir şeklinde yorumlanabildiği ve bu yaklaşımın daha tutarlı olduğu belirtilmiştir. Bu noktada amaç kaçakçılık suçlarına ilişkin filleri işleyen kişiler yönünden bir etkin pişmanlık müessesesi kuralı getirmek ise bu müesseseden yararlanmayı bir idari vergi suçunun oluşumuna (vergi ziyaı) bağlamanın yersiz olduğu, Kanun'un 359. maddesinin 3. fıkrası hükmü lafzi yorum yanında tarihsel ve sistematik yorum yöntemi ile değerlendirildiğinde, kanun koyucunun da bu amaçla 
bu hükme yer verdiği anlaşılacağı, aksi takdirde, muhatapları yönünden adil olmayan uygulama sonuçları ile hukuka aykırı durumların ortaya çıkabileceği anlaşılmaktadır (Yaşin, 2010:205).

Görüldüğü üzere; belirsizlik vergi ziyaına yol açmayan fiillerin kaçakçılık suçu sayılması noktasında yaşanmaktadır ve literatürdeki görüşler bu noktada pişmanlık kurumundan yararlanabilmeyi farklı değerlendirmektedirler.

\subsection{Kişisel Görüşümüz}

Konuyla ilgili farklı görüşlerin ortaya atılması, VUK 359. maddede yer alan "371. maddedeki pişmanlık şartlarına uygun olarak durumu ilgili makamlara bildirenler hakkında bu madde hükümleri uygulanmaz" ifadesinin farklı yorumlanmasından kaynaklanmaktadır.

Kanımızca, 359. maddedeki "371. maddedeki pişmanlık şartlarına uygun olarak" ifadesi, kapsam bakımından bir sınırlama getirmemektedir. 359. maddede yer alan hüküm, sadece 371. maddede düzenlenen "bildirime" ait şartları ifade etmektedir. Yani, aranan şartlar incelemeye başlanmamış olması, takdire sevk edilmemiş olmaması ve ihbarda bulunulmamış olmasıdır. Beyanname verilmesi ve ödeme yapılması bildirime ilişkin şartlar kapsamında değerlendirilemez.

Buna göre, vergi ziyaı cezasını gerektirmeyen fiillerle işlenen kaçakçılık suçları için pişmanlıktan yararlanmak mümkündür. 371. maddede yer alan ziyaı cezasını gerektiren fiiller ifadesi sadece vergi ziyaı cezasının kesilmemesi bağlamında bir kapsam sınırlaması getirmektedir.

Uygulamadaki sorunların giderilmesi bakımından, kanun koyucunun madde metnini yeniden düzenleyerek "vergi ziyaı cezasını gerektiren fiiller" ibaresini netleştirmesinin ve burada amaçladığı mükellef grubunu belirlemesinin tereddütleri gidereceği kanaatindeyiz. Vergi ziyaının ne aşamada yer alacağı fiilin kapsamında mı yoksa somut olarak sonucunda mı hedeflendiğinin kanunda belirtilmesi, özellikle aynı fiili işleyerek vergi ziyaı sonucu yaratmayan ancak kaçakçılık suçuna sebebiyet veren mükellefler arasındaki eşitliğe aykırı uygulamaların önüne geçmiş olacaktır.

\section{Mükellef Nezdinde İncelemeye Başlanılması ve Karşıt İncelemelerin Durumu}

VUK 371/2. maddesinde yer alan "haber verme dilekçesinin yetkili memurlar tarafından mükellef nezdinde herhangi bir vergi incelemesinde başlandığı veya olayın takdir komisyonuna intikal ettirildiği günden evvel (kaçakçılık suçu teşkil eden fiillerin işlendiğinin tespitinden önce) verilmiş ve resmi kayıtlara geçirilmiş olması" ifadesi pişmanlıktan yararlanmanın şartlarından birisi olarak sayılmıştır. Yani mükellefin pişmanlıktan yaralanması için sağlaması gereken bir diğer şart, kendiliğinden beyanından önce hakkında bir vergi incelemesine başlanılmamış olmasıdır. Vergi incelemesine ilişkin usul ve esaslar VUK 134-145 maddeleri arasında düzenlenmiştir. VUK 134. maddede vergi incelemesi, "...ödenmesi gereken vergilerin doğruluğunu 
araştırmak, tespit etmek ve sağlamak" olarak tanımlanmış olup, 371. maddede yer alan "mükellef nezdinde yapılan herhangi bir vergi incelemesine başlandığı andan itibaren", ifadesi mükellefin pişmanlık hükümlerinden yararlanma şansının ortadan kalkacağına vurgu yapmaktadır.

Bu noktada vergi incelemesine ilişkin iki nokta pişmanlık kurumundan yararlanma açısından önem taşımaktadır.

\subsection{Incelemeye Başlama Zamanı Açısından}

Illk önemli nokta vergi incelemesinin ne zaman başlamış olacağıdır. Bu sürenin doğru olarak tespiti mükelleflerin pişmanlık kurumundan yararlanabilmeleri açısından önem taşımaktadır. 6009 sayılı Kanun ile özellikle vergi incelemesine yönelik temel ve köklü değişiklikler yapılmıştır. Bu değişikliklerin başında düzenleme yapılmadan evvel; belirsiz durumda olan vergi incelemesinin başlaması halinin netleştirilmiş olması gelmektedir. Söz konusu düzenlemeden sonra, vergi incelemesinin incelemeye başlama tutanağının düzenlendiği tarihte başladığı artık kesinlik kazanmıştır. Bahse konu tutanak düzenlenmedikçe, vergi incelemesinin başladığının, dolayısıyla konunun vergi idaresinin bilgisine girdiğinin iddia edilmesi hukuken olanaklı değildir. Dolayısıyla, bir vergi incelemesi, ancak mükellef ile birlikte yapılacak vergi incelemesine başlama tutanağının yapıldığı andan itibaren başlamış olacaktır. Kendisine vergi inceleme görevi verilen inceleme elemanı öncelikle vergi dairesinden mükellefin vergi dosyasını alacak ve bu dosyayı kendisine gelen inceleme görevi çerçevesinde değerlendirecektir. Ardından, nezdinde inceleme yapılacak mükellefe bir yazı yazarak verilecek belirli bir süre içinde incelemeye başlama tutanağı yapmak üzere davet edilecek veya işyerine gidilerek süre vermeksizin incelemeye başlama tutanağı düzenlenecektir. Yazılı davet yapılacak ise, bu durumda VUK'nun 14. maddesinde hükme bağlanmış olan yasal ve yönetsel sürelere uyulması gerekmektedir. Bu madde uyarınca, yasada açıkça yazılı olmayana hallerde 15 günden aşağı olmamak kaydıyla bu süreyi, tebliği yapacak olan idare belirlemekte ve ilgiliye tebliğ etmektedir. Bu hüküm uyarınca, nezdinde inceleme yapılacak kişi inceleme elemanının bulunduğu yere incelemeye başlama tutanağı yapmak üzere çağrıldığı (davet edildiği) takdirde VUK'nun 14. maddesi uyarınca mükellefe en az 15 gün süre verilmesi gerekmektedir (Erol, 2012:32).

Mükellefe yasal hakkı olan ve idarece verilen bu en az 15 günlük süre içerisinde vergi incelemesinin hukuken başladığının ileri sürülmesi mümkün değildir. Çünkü, VUK'nun 140/2. maddesi uyarınca vergi incelemesi ancak incelemeye başlama tutanağının düzenlenmesinden itibaren başlamaktadır. Incelemeye başlama tutanağı yapmak üzere davet edilen mükellef bu süre içinde VUK'nun 371. maddesinden yararlanabilir mi? Ayrıca, henüz incelemeye başlama tutanağı düzenlememiş inceleme elemanı mükellefin pişmanlık istemini vergi dairesine incelemeye başlama tutanağının bir örneğini göndermeden bir resmi yazıyla kesebilir mi?

İncelemeye başlama tutanağı yapmak üzere davet edilen ve kendisine 15 gün süre tanınmış olan mükellefin bu süre içinde yasal defter ve belgelerinde riskli unsurlar tespit etmişse ya da zaten bunları biliyorsa bu süre içinde pişmanlıkla düzeltme beyannamesi vermesinin önünde yasal bir engel bulunmamaktadır. Kısaca, kendisi 
yapılacak bir vergi incelemesine başlama tutanağı için daireye davet edilen mükellef, incelmeye başlama tutanağının altına imza koyana ve bu tutanağın bir örneği kendisine tebliğ edilene kadar pişmanlık hükümlerinden yararlanabilecektir.

Kendisine vergi inceleme görevi gelen bir vergi inceleme elemanının, incelemeye başlama tutanağını düzenlemeden önce mükellefin VUK'nun 371. maddesinden gelen pişmanlık hakkını bir yazıyla ortadan kaldırması da hukuken olanaklı değildir (Erol, 2013: 18).

Bu noktada, önemli bir husus da, vergi inceleme elemanının aldığı tutanağın bir örneğini vergi dairesine gönderinceye kadar geçecek sürede mükellefin pişmanlıktan yararlanıp yararlanamayacağına ilişkindir. Ancak bu noktada kanun hükmü açıktır ve incelemeye başlanılması ile pişmanlık şartları ihlal edildiğinden dolayı, mükellef aradaki sürede de pişmanlık dilekçesi verse, hükümlerden yararlandırılamaz. Vergi dairesi sehven bu aralık zarfında, mükellefi pişmanlıktan yararlandırırsa bile, işlem sonradan düzeltilmeli ve KSS (Kanuni Süresinden Sonra) şeklinde verilen beyannamelere ilişkin işlemlere göre, mükellefe cezalı tarhiyat yapılmalıdır (Mutlu, 2015: 227).

\section{2.İncelemenin Tür ve Kapsamı Açısından}

Inceleme ile ikinci önemli nokta ise; mükellef nezdinde yapılacak incelemenin, kapsamı ve türü açısından bir sınırlamanın olmamasıdır. Kanunda geçen herhangi bir vergi incelemesi ibaresi bu yargıya ulaşılmasına neden olmaktadır. Bu incelemenin mükellef açısından tam ya da kısmi inceleme veya karşıt inceleme olmasının pişmanlık beyanına olan olumsuz etkisinde bir ayrım gözetilmemiştir(Karakoç, 1997: 55). Ancak bazı hallerde, "karşıt inceleme" olarak isimlendirilen fakat kanaatimizce sınırlı inceleme şeklinde de nitelendirilebilecek ve hakkında inceleme yapılan bir mükellefin ticari ilişki içinde olduğu ve belge alıp verdiği karşı tarafın da incelendiği bir durum da söz konusu olabilmektedir. Bu durumda örneğin sahte belge düzenlendiği tespit edilen bir mükellef hakkında vergi inceleme, vergi tekniği ve vergi suçu raporu düzenlenmekte, karşıt incelemeyi yapan vergi inceleme elemanının bu raporlarda bu mükelleften belge almış olan diğer kişi veya kurumlar hakkında sahte belge kullanmaktan dolayı vergi incelemesi yapılması gerektiği belirtilmektedir. Yani sahte belge aldığı tespit edilen hakkında henüz bir vergi incelemesi başlatılmamıştır (Somuncu\&Değirmendereli, 2015: 100). Sadece tespit yapılmıştır. Bu durumda karşıt inceleme "herhangi bir vergi incelemesi" kapsamında yer almakta mıdır? Nezdinde karşıt inceleme yapılan mükellef pişmanlık ve ıslah hükümlerinden yararlanabilecek midir?

İdarece sahte belge alışı konusu hakkında tespit yapılan veya bu konuda kontrol edilmek istenen mükelleflere karşıt inceleme yazısı gönderilmekte ve bu yazıda mal/hizmet satın almış oldukları, hakkında vergi incelemesi devam eden, vergi suçu ve vergi tekniği raporu düzenlenen mükellefe ilişkin bazı bilgiler( faturalar, faturalara ilişkin ödeme belgeleri, söz konusu faturalardaki KDV tutarlarının beyannamede indirim konusu yapılıp yapılmadığı, mükellef kurum ile kim aracılı̆̆ı ile ticari ilişki kurulduğu, mal/hizmetlerin gerçekten alınıp alınmadığı, ne amaçla kullanıldığının açıklaması) istenmektedir. Söz konusu bilgi ve belgelerin temini için mükellefe karşıt inceleme yazısının tebliğinden itibaren 15 günlük süre tanınmaktadır. Mükellef karşıt inceleme 
tutanağında istenen belgelerin idareye ibrazı esnasında kendisine belgeleri teslim ettiğine dair bir evrak imzalatılmaktadır.

Kanunda, yapılan incelemenin türü ve kapsamı ile ilgili olarak herhangi bir belirleme yapılmadığı için, ister tam veya sınırlı isterse karşıt inceleme mahiyetinde olsun, yükümlü hakkında vergi incelemesine başlanılması, pişmanlıkla beyanname verilmesi imkanını ortadan kaldıracaktır (Edizdoğan vd.,2015: 192).

Ancak bir mükellef hakkında inceleme başlatılması onunla ticari ilişki içine girmiş diğer mükelleflerin pişmanlık ve ıslahtan yararlanmasına engel olarak görülmemelidir (Yıldırım, 2013: 187). Nitekim Danıştay 4. Dairesi 26.10.1963 Tarih, E.1960/3152,K.1963/3036 Sayılı kararında; "Alıcı şahıs nezdinde incelemeye başlanılmış olması, satıcının bu hükme uygun şekilde yaptığı pişmanlık talebinin reddini gerektirmez" şeklinde hüküm vermiştir. Bu noktada nezdinde karşıt inceleme başlatılan mükelleflerin kendilerine tanınan 15 günlük süre içerisinde pişmanlıkla beyanda bulunmalarının usul yönünden bir sakınca içermediği açıktır. Belgelerin ibrazından sonra yapılan pişmanlık beyanlarında ise res'en tarhiyat ile karşılaşılması riski mevcuttur. Çünkü idarece yapılmış bir tespit ve bu tespit üzerine mükelleften istenen bilgi ve belgeler mevcuttur. Söz konusu bilgi ve belgelerin istendiği tutanakta VUK 134. ve müteakip maddelerince yapılmakta olan bir vergi incelemesine esas teşkil etmek üzere bu belgelerin istenildiği belirtilmekte, belgelerin verilen sürede ibraz edilmemesi halinde özel usulsüzlük cezası kesileceği ayrıca belirtilmektedir. Buradan da anlaşılacağı gibi nezdinde karşıt inceleme yapılan mükellef de bir bakıma idarenin radarına girmiş durumdadır. Bu itibarla defter ve belgelerinde vergi kanunlarına aykırılık içeren bir durum varsa veya bunu tespit etmişse söz konusu hususu kendisinden talep edilen belgeleri idareye sunmadan evvel pişmanlık beyanı ile bildirmesi daha doğru olacaktır.

\section{Sonuç}

Pişmanlık ve ıslah kurumu hiç beyanname vermemek ya da verdiği beyannamede yanlış veya eksik bilgi sunmak suretiyle vergi idaresinden gizlenen bilgilerin idareye bildirilmesini teşvik etmektedir. Bu sayede mükellef, sorumlu ya da fiile iştirak eden kişi oluşturduğu vergi kaybını gidermek yoluyla normalde idarenin bilgisi dışında bulunan ve doğal olarak kayıtdışında olan vergi kaynağının kayıt altına alınmasını sağlamaktadır. Kanun kayıtdışılıkla çok yakın ilişkisi olan vergi kaçakçılığı suçunu da pişmanlık ve ıslah kapsamına alarak bir yandan kayıtlı ekonomiye de katkı sağlamaktadır.

Uygulamada pişmanlık ve ıslah kurumu ile problemlerin ağırlıklı olarak kurumun belirsiz yönlerinin yasama organı yerine idare tarafından yapılan düzenlemelerle ya da yargı kararları doğrultusunda giderilmeye çalışılmasından kaynaklandığı görülmektedir.

Vergi ziyaı cezasını gerektiren haller ile gerektirmeyen hallerde pişmanlık ve ıslahtan yararlanma koşullarının net bir şekilde belli olmaması bu alanda yaşanan en önemli sorunlardan birisidir. Bu itibarla pişmanlık ve ıslah kurumundan yararlanma şartları vergi ziyaına sebebiyet verilmesi ve kaçakçılık suçları açısından değerlendirilecek olursa; 


\section{Kapsam şartları;}

-Beyana dayanan vergilerden olması

-(Beyana dayanan vergilerde)Vergi ziyaını gerektiren fiillerin işlenmesi

\section{Bildirim şartları;}

-Mükellefin yetkili makamlara dilekçe ile haber verme tarihinden önce haber verilen husus hakkında ihbarda bulunmamış olması

-Mükellefin yetkili makamlara dilekçe ile haber verme tarihinden önce yetkili memurlar tarafından mükellef nezdinde herhangi bir vergi incelemesine başlanılmamış olması

- Mükellefin yetkili makamlara dilekçe ile haber verme tarihinden önce takdire sevk işleminin yapılmamış olması

\section{Beyan ve ödeme şartları,}

-Hiç verilmemiş beyannamelerin mükellefin haber verme dilekçesinin verildiği tarihten başlayarak on beş gün içinde verilmesi

-Eksik veya yanlış yapılan vergi beyanının mükellefin keyfiyeti haber verme tarihinden başlayarak on beş gün içinde tamamlanması veya düzeltilmesi

-Mükellef tarafından haber verilen ve ödeme süresi geçmiş bulunan vergilerin, ödemenin geciktiği her ay ve kesri için, 6183 sayılı kanunun 51. maddesinde yer alan nispette uygulanacak gecikme zammı oranında bir zamla birlikte haber verme tarihinden başlayarak on beş gün içinde ödenmesi şeklinde bir sınıflandırma yapılabilir.

Söz konusu sınıflandırmanın tablo şeklindeki gösterimi aşağıda yer almaktadır.

Tablo 1: Pişmanlıktan yararlanma şartlarının sınıflandırılması

\begin{tabular}{|l|c|c|}
\hline Sınıflandırma & Kaçakçılık Cezası ççin & Vergi Ziyaı Cezası çcin \\
\hline Kapsam Şartları & Gerekli Değil & Gerekli \\
\hline Bildirim Şartları & Gerekli & Gerekli \\
\hline Beyan ve Ödeme Şartları & Gerekli değil & Gerekli \\
\hline
\end{tabular}

Kaçakçılık suçlarının da pişmanlık ve ıslah kurumu kapsamında yer aldığı göz önünde bulundurulduğunda; kaçakçılık suçları gibi vergi kanunlarının en ağır hükümlerinin yer aldığı suçlara sebebiyet verilmesinde vergi ziyaının oluşması şartı aranmazken, pişmanlık ve ıslah kurumundan yararlanabilmek için vergi ziyaına sebebiyet verme ön koşulu içeren bir madde metnin varlığı hem mükellefler arasında eşitsizliğe yol açmakta hem de pişmanlık kurumundan beklenen yararın elde edilmesinin önüne geçmektedir. Madde metninde bu eşitliğe aykırı bu durumun önüne geçecek şekilde değişiklikler yapılması yerinde olacaktır. 
Bu noktada; özellikle pişmanlıktan yararlanmanın ön koşulunu vergi ziyaına sebebiyet verilmesi olarak düzenleyen "vergi ziyaı cezasını gerektiren fiilleri işleyen mükellefler" ifadesi netleştirilmeli, vergi kanunlarına aykırı olduğu halde, vergi ziyaına sebebiyet verilmediği için pişmanlıktan yararlanmama durumu ortadan kaldırılmalıdır.

Bu aksaklıkların çözüme bağlanmış olması, eşitliğe aykırı durumların ortaya çıkmasını önlemesinin yanında pişmanlık ve ıslah kurumunun uygulamadaki etkinliğinin artırılmasını da sağlayacaktır.

\section{KAYNAKÇA}

Demirci, A. (2009). "Pişmanlık ve Islah Uygulamasında Yaşanan Sorunlar", Vergi Dünyası, No: 3(331), ss.156-162.

Doğrusöz, E. (2003). "Pişmanlık ve Islah Müessesesi- Mücbir Sebep Kavramı Iliş̧kisi”, Yaklaşım Dergisi, No: 11(123), ss.218-223.

Donay, S. (2008). Ceza Mahkemesinde Yargılanan Vergi Suçları, İstanbul: Beta Yayınları.

Dönmez, R. (2009). Teoride ve Uygulamada Vergi Afları, Eskişehir: Anadolu Üniversitesi Yayını.

Edizdoğan, N. \& Taş, M. \&Çelikkaya, A., (2007).Vergi Ceza ve Yargılama Hukuku, Bursa: Ekin Basın Yayın Dağıtım.

Erman, S. (1988). Vergi Suçları, İstanbul: i.ü. Fen Fakültesi Döner Sermaye İşletmesi Prof. Dr. Nazım Terzioğlu Basım Atölyesi.

Erol, A. (2012). "Pişmanlık ve Islah-III", Yaklaşım Dergisi, No: 20 (239),ss.31-34.

Erol, A. (2013). "Pişmanlık ve Islah-V", Yaklaşım Dergisi, No: 21 (241),ss.17-19

Karakoç, Y. (1997). Türk Vergi Ceza Hukukunda Pişmanlık ve Islah, 2. Baskı, İzmir: DEÜ Hukuk Fakültesi Döner Sermaye İşletmesi Yayın No:76.

Karakoç, Y. (2007). Genel Vergi Hukuku, Genişletilmiş 4. Bası, Ankara: Yetkin Yayınları.

Kızılot, Ş. \& Kızılot, Z. (2010).Kaçakçılık Suçları ve Naylon Fatura ihtilafları, 3. Baskı, Ankara: Yaklaşım Yayıncılık.

Kocahanoğlu, O.S. (1985). "Vergi Hukukunda Pişmanlık Nedir?”, Iktisat ve Maliye Dergisi, C.XXXII (7), ss.4-10.

Mutlu, E. (2015). “Pişmanlık ve Islah Müessesinde Kendiliğinden Haber Verme, İhbar ve Incelemeye Başlanması”, E-Yaklaşım, No: 23 (269), ss. 226-231, www.yaklasim.com, (20.11.2015)

Şenyüz, D. (2015). Vergi Ceza Hukuku, 8.Baskı, Bursa: Ekin Basım Yayın Dağıtım.

Somuncu, A. \& Değirmendereli, A. (2015). Türk ve Alman Vergi Hukukunda Pişmanlık, Ankara: Seçkin Yayıncılık. 
Taş, M. (1997). “Mücbir Sebepler Dava Açma Süresini Etkiler mi?”, Yaklaşım Dergisi, 5 (53), ss.156-157.

Yaşin, M. (2010). “Vergi Ziyaına Sebebiyet Vermeyen Kaçakçılık Suçlarında Pişmanlık Müessesinden Yararlanılabilir mi?", Yaklaşım Dergisi, 18 (206), ss.203-208, www.yaklasim.com, $(21.11,2015)$.

Yerlikaya, G.K. (2012). "Türk Vergi Hukukunda Mücbir Sebep Halinin Dava ve Temyiz Süresini Durdurup Durdurmayacağı Sorunu", Yalova Üniversitesi Hukuk Fakültesi Dergisi, No:1 (1), ss.43-56

Yıldırım, Z. (2013). Vergi Ceza Hukukunda Pişmanlık ve Islah, Ankara: Adalet Yayınevi. 